\title{
A PROVA NO PROCESSO PENAL: A IMPORTÂNCIA DA VALORAÇÃO DO LASTRO PROBATÓRIO E DE SEU CONTROLE POR MEIO RECURSAL
}

\author{
EVIDENCE IN CRIMINAL JUSTICE: THE IMPORTANCE OF THE EVIDENCE \\ EVALUATION AND ITS CONTROL IN APPEAL
}

\author{
PRUEBA EN EL PROCESO PENAL: LA IMPORTANCIA DE LA VALORACIÓN DE \\ LAS PRUEBAS Y DE SU CONTROL EN APELACIÓN
}

\author{
VinICIUS GOMES DE VASCONCELLOS \\ http://orcid.org/0000-0003-2020-5516 / http://lattes.cnpq.br/9628659956663949 / vgomesv@gmail.com
}

Pós-doutorando pela Universidade Federal do Rio de Janeiro (RJ). Doutor pela Universidade de São Paulo (USP), com período de sanduíche (PDSE/Capes) na Universidad Complutense de Madrid. Pesquisador visitante no Max Planck Institute for Foreign and International Criminal Law (2014 e 2017). Professor do mestrado em Direito do Centro Universitário FIEO (Osasco/SP) e da graduação das Faculdades Integradas Campos Salles (SP). Osasco, SP, Brasil.

\begin{abstract}
RESUMO
Este artigo discute premissas importantes relacionadas à prova penal, almejando definir a sua função e os modelos para sua valoração na dogmática processual contemporânea. Os problemas que guiam o desenvolvimento desta pesquisa são: 1) qual a função da prova no processo penal?; 2) a decisão judicial sobre valoração das provas é livre?; e, 3) o juízo sobre os fatos na decisão judicial deve ser submetido a controle? Sustenta-se a tese de que, embora a persuasão do juiz seja elemento a ser considerado como dado de realidade, a valoração probatória deve ser orientada por critérios racionais e objetivos, cujo controle somente será possível em razão de uma ligação cognitiva com os fatos, que aportará critérios e limitará o processo de tomada de decisão pelo julgador. Assim, ressalta-se a indispensabilidade da motivação e do controle sobre o juízo fático da decisão penal, especialmente por meio do direito ao recurso sobre a condenação. Desse modo, este trabalho contribui para a consolidação de uma dogmática processual penal que propicie uma efetiva limitação aos espaços de discricionariedade decisória e, assim, ao poder punitivo estatal.
\end{abstract}

Palavras-chave: Controle; Decisão Penal; Fatos; Processo Penal; Prova.

\section{ABSTRACT}

This article discusses important premises related to criminal evidence, aiming to define its function and models for its evaluation in contemporary procedural dogmatics. The problems that guide the development of this research are: 1) what is the role of evidence in criminal procedure?; 2) is the evidence evaluation in judicial decision free? and, 3) the judgment on the facts in the judicial decision should be subject to control? The thesis is that, although the persuasion of the judge is an element to be considered as a reality, probative evaluation must be guided by rational and objective criteria, which control will only be possible because of a cognitive connection with the facts, that will provide criteria and limit to the decision-making process by the court. Therefore, it is important to emphasize the indispensability of motivation and control over the factual basis of the criminal decision, especially through the right to appeal against conviction. In that way, this work contributes to the consolidation of a criminal procedural dogmatics that allows an effective limitation to the spaces of judicial discretion and, thus, to the punitive power of the state.

Keywords: Control; Criminal decision: Criminal evidence; facts; evidence.

\section{RESUMEN}

Este artículo discute premisas importantes relacionadas a la prueba penal, aspirando definir su función y los modelos para su valoración en la dogmática procesal contemporánea. Los problemas que guían el desarrollo de esta 
investigación son: 1) cuál es la función de la prueba en el proceso penal?; 2) la decisión judicial sobre la valoración de las pruebas es libre ?; y, 3) el juicio sobre los hechos en la decisión judicial debe ser sometido a control? Se sostiene la tesis de que, aunque la persuasión del juez sea elemento a ser considerado como dado de realidad, la valoración probatoria debe ser orientada por criterios racionales y objetivos, cuyo control sólo será posible en razón de una conexión cognitiva con los hechos, que aportará criterios y limitará el proceso de toma de decisión por el juzgador. Así, se resalta la indispensabilidad de la motivación y del control sobre el juicio fáctico de la decisión penal, especialmente por medio del derecho al recurso sobre la condena. De este modo, este trabajo contribuye a la consolidación de una dogmática procesal penal que propicie una efectiva limitación a los espacios de discrecionalidad decisiva y, así, al poder punitivo estatal.

Palabras clave: Decisión penal; hechos; pruebas; control; proceso penal.

\section{SUMÁRIO}

INTRODUÇAO; 1 A FUNÇÃO DA PROVA NO PROCESSO PENAL: ENTRE A RACIONALIDADE DA COGNIÇÃO E A FACTICIDADE DA PERSUASÃO DO JULGADOR; 2 MODELOS DE VALORAÇÃO PROBATÓRIA E SEU CONTROLE POR MEIO DE RECURSOS; 3 A IMPORTÂNCIA DO CONTROLE SOBRE O JUÍZO DE FATOS PARA A DECISÃO EM ÂMBITO CRIMINAL; CONCLUSÃO; REFERÊNCIAS.

\section{INTRODUÇÃO}

A “reconstrução dos fatos"1 passados é um ponto fundamental do processo penal, considerando-se sua a função de verificar a congruência entre a acusação imputada e o lastro probatório produzido por iniciativa das partes. 0 momento da valoração na formação da decisão judicial, contudo, carece de maior atenção da doutrina ${ }^{2}$, visto que é comumente estudado sem maiores cautelas ou relegado à aceitação do mito de uma convicção pessoal do magistrado, maculado por um subjetivismo exacerbado, quase místico ${ }^{3}$.

Diversamente da premissa majoritariamente aceita em momentos passados, a análise judicial das provas não pode ser concebida como uma simples percepção sobre fatos evidentes, em que inexiste espaço para qualquer tipo de valoração ou influência do julgador ${ }^{4}$. 0 processo é

\footnotetext{
1 DUCLERC, Elmir. Prova Penal e Garantismo: uma investigação crítica sobre a verdade fática construída através do processo. Rio de Janeiro: Lumen Juris, 2004. p. 02; GOMES FILHO, Antonio Magalhães. Direito à prova no processo penal. São Paulo: RT, 1997. p. 18; LOPES JR., Aury. Direito Processual Penal. 9. ed. São Paulo: Saraiva, 2012. p. 535-536.

2 "Somando-se as três causas aqui identificadas - 10) caráter refratário do direito probatório ao discurso jurídico; 20) natural tendência ao subjetivismo; 3o) prevalência da tradição positivista - facilmente chegase à consequência: a doutrina culminou por 'eclipsar e desvalorizar o aspecto normativo da teoria da prova judicial, certamente não eliminado, em que pese a abolição das provas legais', empobrecendo enfim o direito probatório" (KNIJNIK, Danilo. A prova nos juízos cível, penal e tributário. Rio de Janeiro: Forense, 2007. p. 6).

${ }^{3}$ GASCÓN ABELLÁN, Maria. Los hechos en el derecho. Bases argumentales de la prueba. 3. ed. Madrid: Marcial Pons, 2010. p. 12.

${ }^{4}$ ANDRÉS IBÁÑNEZ, Perfecto. Acerca de la motivación de los hechos en la sentencia penal. Doxa: Cuadernos de Filosofia del Derecho, n. 12, p. 257-299, 1992. p. 265.
} 
pautado por incertezas e, por óbvio, a valoração probatória não foge a essa lógica ${ }^{5}$. Como será analisado neste trabalho, o exame do lastro probatório é ponto crucial, determinando espaço de possível arbítrio judicial que precisa ser limitado a partir de critérios racionais e objetivos, controláveis por meio de mecanismos internos e externos ao processo, entre eles o recurso sobre a condenação, foco desta pesquisa.

Diante disso, este artigo discute premissas relevantes relacionadas à prova penal, almejando definir a sua função e os modelos para sua valoração na dogmática processual contemporânea. A partir de tal arcabouço, ressalta-se a importância do controle sobre o juízo fático realizado pelo julgador de primeiro grau, o que somente é possível a partir da necessidade de critérios objetivos e racionais para a valoração da prova. Portanto, este trabalho contribui para a consolidação de uma dogmática processual penal que propicie uma efetiva limitação aos espaços de discricionariedade decisória e, assim, ao poder punitivo estatal. Para tanto, analisarse-á (1) a função da prova, (2) os modelos de valoração e suas possibilidades de controle e, por fim, (3) a importância da revisão recursal sobre o juízo fático na justiça criminal.

De tal sorte, os problemas que guiam o desenvolvimento desta pesquisa são: 1) qual a função da prova no processo penal?; 2) a decisão judicial sobre valoração das provas é livre?; e, 3) o juízo sobre os fatos na decisão judicial deve ser submetido a controle? Sustenta-se a tese de que, embora a persuasão do juiz seja elemento a ser considerado como dado de realidade, a valoração probatória deve ser orientada por critérios racionais e objetivos, cujo controle somente será possível em razão de uma ligação cognitiva com os fatos, que aportará critérios e limitará o processo de tomada de decisão pelo julgador. Assim, ressalta-se a indispensabilidade da motivação e do controle sobre o juízo fático da decisão penal, especialmente por meio do direito ao recurso sobre a condenação .

\section{A FUNÇÃO DA PROVA NO PROCESSO PENAL: ENTRE A RACIONALIDADE DA COGNIÇÃO E A FACTICIDADE DA PERSUASÃO DO JULGADOR}

\footnotetext{
${ }^{5}$ FERRER BELTRÁN, Jordi. La valoración racional de la prueba. Madrid: Marcial Pons, 2007. p. 26; IACOVIELLO, Francesco M. La motivazione della sentenza penale e il suo controllo in cassazione. Milano: Giuffrè, 1997. p. 41.

${ }^{6}$ Sobre isso, ver: VASCONCELLOS, Vinicius G. Direito ao Recurso no Processo Penal: conteúdo e dinâmica procedimental de um modelo de limitação do poder punitivo estatal pelo controle efetivo da sentença condenatória. 2017. Tese (Doutorado em Direito) - Faculdade de Direito, Universidade de São Paulo, São Paulo.
} 
Antes de enfocar-se na importância do controle sobre a valoração probatória, devem ser assentadas certas premissas ao estudo da prova no processo penal. Há muito se discute a sua função, que diverge desde uma inconsequente busca incondicional da verdade à centralização no subjetivismo do convencimento judicial. A adoção de um posicionamento nessa temática é indispensável para a definição dos contornos essenciais da dogmática processual penal, influenciando profundamente na concepção sobre a possibilidade de controle da decisão judicial.

Duas são as principais teorias relacionadas à função da prova. Por um lado, afirma-se que a prova é meio para busca da verdade de modo a possibilitar uma decisão justa, que corresponda com os fatos ocorridos no passado. Por outro, há quem, problematizando a noção de verdade no processo, sustente que a prova é elemento direcionado ao convencimento do julgador, ressaltando a função estratégica da atuação das partes para a obtenção de um resultado processual positivo. Sem dúvidas, a temática da verdade envolve questões extremamente complexas, relacionadas a problemas filosóficos de caráter perene na discussão científica ${ }^{7}$. Contudo, nos limites propostos pelo objeto deste artigo, pretende-se enfocar na produção na área do direito processual sobre o tema.

Com relação ao primeiro posicionamento, pode-se afirmar que parte majoritária da doutrina afirma que a função da "atividade jurisdicional criminal" é a descoberta da verdade ${ }^{8}$, o que determina essencialmente a sua visão em relação às provas. Por certo, atualmente mostrase insustentável qualquer posição extremada, que perquira a revelação de uma verdade "real ou material”, pois fragilizada por críticas acerca da inviabilidade de obtenção desse conhecimento pretensamente integral e inquestionável ${ }^{9}$. Igualmente se afirma, entretanto, que não é possível

\footnotetext{
7 PACELLI, Eugênio. Verdade judicial e sistema de prova no processo penal brasileiro. In: PEREIRA, Flávio Cardoso. Verdade e prova no processo penal. Brasília: Gazeta Jurídica, 2016. p. 91-93.

${ }^{8}$ DIAS, Jorge de Figueiredo. Direito Processual Penal. Coimbra: Coimbra Editora, 2004. p. 43; BETTIOL, Giuseppe. Instituciones de Derecho Penal y Procesal. Barcelona: Bosch, 1973. p. 250; CRUZ, Rogerio Schietti M. Garantias Processuais nos Recursos Criminais. 2. ed. São Paulo: Atlas, 2013. p. 1, nota 1.

${ }^{9}$ ZILLI, Marcos Alexandre Coelho. A Iniciativa Instrutória do Juiz no Processo Penal. São Paulo: RT, 2003. p. 114; FERRAJOLI, Luigi. Direito e Razão. Teoria do Garantismo Penal. 4. ed. São Paulo: RT, 2014. p. 46 50; PINTO, Felipe Martins. Introdução crítica ao processo penal. Belo Horizonte: Del Rey, 2012. p. 79119; TARUFFO, Michele. La verità nel processo. In: PEREIRA, Flávio Cardoso. Verdade e prova no processo penal. Brasília: Gazeta Jurídica, 2016. p. 255-256. Sustentando a apuração da verdade material como "o dado mais relevante do precípuo escopo do processo penal", ver: TUCCI, Rogério Lauria. Direitos e garantias individuais no processo penal brasileiro. 4. ed. São Paulo: RT, 2011. p. 45. Sobre essa discussão, ver: GRINOVER, Ada Pellegrini. Provas ilícitas, interceptações e escutas. Brasília: Gazeta Jurídica, 2013. p. 87-90; GRINOVER, Ada Pellegrini. Verdade real e verdade formal? Um falso problema. In: PEREIRA, Flávio Cardoso. Verdade e prova no processo penal. Brasília: Gazeta Jurídica, 2016. p. 1-13.
} 
abrir mão da busca da verdade, pois determinante da legitimidade da justiça criminal de um modo amplo ${ }^{10}$.

A busca da verdade pautada por limitações epistemológicas e intrinsecamente relacionadas ao mecanismo processual é uma premissa adotada por aqueles que defendem a função cognitiva ou racionalista da prova ${ }^{11}$. Embora mantenham-se atrelados a essa premissa ao configurar um "modelo segundo o qual os procedimentos de determinação dos fatos se dirigem à formulação de enunciados fáticos que serão verdadeiros se os fatos que descrevem tenham ocorrido ou falsos em caso contrário"12, assumem as limitações do conhecimento judiciário e, assim, adotam uma noção de probabilidade ${ }^{13}$. Ou seja, afirma-se que um fato ("p") está provado quando "houver elementos de prova suficientes a favor de p"14.

Segundo Ferrer Beltrán, a concepção racionalista da prova caracteriza-se por: adotar o método da corroboração e da refutação de hipóteses para valoração probatória; aderir a uma visão limitada do princípio da imediação; fortalecer a exigência de motivação da decisão sobre fatos; e defender um sistema recursal que ofereça ampla possibilidade de controle e revisão da decisão em instâncias superiores ${ }^{15}$. Assim, o processo penal, pautado pela proteção de direitos e garantias fundamentais e concebido como condição de legitimidade da justiça criminal,

${ }^{10}$ BADARÓ, Gustavo Henrique. Ônus da prova no processo penal. São Paulo: RT, 2003. p. 24-26; BADARÓ, Gustavo H. Editorial dossiê "Prova penal: fundamentos epistemológicos e jurídicos". Revista Brasileira de Direito Processual Penal, Porto Alegre, vol. 4, n. 1, p. 43-80, jan./abr. 2018. p. 46-48; Disponível em: <http://dx.doi.org/10.22197/rbdpp.v4i1.138>. Acesso em: 19 ago. 2018. BARROS, Marco Antonio de. A busca da verdade no processo penal. 4. ed. São Paulo: RT, 2013. p. 26-29; NIEVA FENOLL, Jordi. La valoración de la prueba. Madrid: Marcial Pons, 2012. p. 147-149.

11 GOMES FILHO, Antonio Magalhães. Direito à prova no processo penal. São Paulo: RT, 1997. p. 55; GASCÓN ABELLÁN, Maria. Los hechos en el derecho. Bases argumentales de la prueba. 3. ed. Madrid: Marcial Pons, 2010. p. 110; TARUFFO, Michele. Consideraciones sobre prueba y motivación. Jueces para la democracia, Madri, v. 59, p. 71-79, jul. 2007. p. 76; FERRER BELTRÁN, Jordi. La valoración racional de la prueba. Madrid: Marcial Pons, 2007. p. 64. Sobre a relação entre verdade e justificação racional da sentença, ver: CAPRIOLI, Francesco. Verità e giustificazione nel processo penale. Revista Brasileira de Direito Processual Penal, Porto Alegre, vol. 3, n. 1, p. 317-342, jan./abr. 2017. Disponível em: <https://doi.org/10.22197/rbdpp.v3i1.30>. Acesso em: 19 ago. 2018.

12 GASCÓN ABELLÁN, Maria. Los hechos en el derecho. Bases argumentales de la prueba. 3. ed. Madrid: Marcial Pons, 2010. p. 49 (tradução livre).

${ }_{13}$ BADARÓ, Gustavo Henrique. Processo Penal. 2. ed. Rio de Janeiro: Elsevier, 2014. p. 263; BADARÓ, Gustavo Henrique. Manual dos Recursos Penais. São Paulo: RT, 2016. p. 55. Em crítica a tal posição: KHALED JR., Salah H. A busca da verdade no processo penal. Para além da ambição inquisitorial. São Paulo: Atlas, 2013. p. 184. Sobre os limites e perigos na utilização de probabilidade e estatística na valoração probatória, ver: SÁNCHEZ-RUBIO, Ana. Los peligros de la probabilidad y la estadística como herramientas para la valoración jurídico-probatoria. Revista Brasileira de Direito Processual Penal, Porto Alegre, vol. 4, n. 1, p. 183-214, jan./abr. 2018. Disponível em: <https://doi.org/10.22197/rbdpp.v4i1.118>. Acesso em: 19 ago. 2018.

${ }^{14}$ FERRER BELTRÁN, Jordi. Prueva y verdade en el derecho. 2. ed. Madrid: Marcial Pons, 2005. p. 35 (tradução livre).

15 FERRER BELTRÁN, Jordi. La valoración racional de la prueba. Madrid: Marcial Pons, 2007. p. 64 (tradução livre). 
pressupõe um "cognitivismo processual na determinação do fato criminoso"16, que requer a "verificabilidade ou refutabilidade das hipóteses acusatórias, em virtude de seu caráter assertivo, e sua comprovação empírica, em virtude de procedimentos que permitem tanto a verificação como a refutação"17.

Ao mesmo tempo em que apresenta pontos que devem ser considerados, as teorias pautadas essencialmente pela busca da verdade como função da prova e do processo padecem de fragilidades passíveis de fundamentadas críticas. Segundo Aury Lopes Jr.:

Sob qualquer ângulo que se analise a questão, o que se vê é um labirinto de subjetividades e contaminações que não permite atribuir ao processo a função de, através da sentença, relevar a 'verdade' (nem real, nem processual, pois o problema está na 'verdade')", de modo a concluir que tal conceito "contém um excesso epistêmico. ${ }^{18}$

Diante dos problemas relacionados às tendências autoritárias ocasionadas pelo aceite da "busca da verdade" como elemento essencial e basilar, sustenta-se neste artigo que é necessário deslocar tal dispositivo na construção da dogmática do processo penal. Inevitavelmente, ele não será totalmente excluído, mas não pode ser concebido como o fundamento ou a função do processo penal. Pensa-se que o julgador deve considerar que o processo determina uma "reconstrução histórica dos fatos" a partir de rastros do passado, de modo que a versão adotada refletirá tal história de um modo analógico, mas nunca integral, abrangente e inquestionável ${ }^{19}$.

Como consequência de tal postura, deve-se assumir que a verdade não é elemento de legitimação que autorize eventual postura ativa do julgador em sua busca ou que se coloque como pedra de toque da teoria do processo penal ${ }^{20}$. Em realidade, ela não é determinante da função do processo ou do julgador ${ }^{21}$, mas está intrinsecamente relacionada à prova, como caracterizadora de uma relação instrumental com a realidade, de modo a autorizar um controle sobre a decisão judicial em relação aos fatos julgados e à valoração realizada. Conforme Salah

16 BADARÓ, Gustavo H. A busca da verdade no processo penal e os seus limites: ainda e sempre o problema do prazo de duração da interceptação telefônica. In: SANTORO, Antonio E.; MADURO, Flávio M. (orgs.). Interceptação telefônica. Belo Horizonte: D’Plácido, 2016. p. 192.

${ }^{17}$ FERRAJOLI, Luigi. Direito e Razão. Teoria do Garantismo Penal. 4. ed. São Paulo: RT, 2014. p. 40.

18 LOPES JR., Aury. Direito Processual Penal. 9. ed. São Paulo: Saraiva, 2012. p. 573. Em sentido oposto, ver: TARUFFO, Michele. La prueba de los hechos. 4. ed. Madrid: Trotta, 2011. p. 176-178.

19 KHALED JR., Salah H. A busca da verdade no processo penal. Para além da ambição inquisitorial. São Paulo: Atlas, 2013. p. 591.

${ }^{20}$ LOPES JR., Aury. Direito Processual Penal. 9. ed. São Paulo: Saraiva, 2012. p. 573.

21 "Nesse panorama de incerteza epistemológica, o juiz não registra uma verdade objetiva, mas escolhe a hipótese mais provável. Em resumo, não investiga, mas decide.". IACOVIELLO, Francesco M. La motivazione della sentenza penale e il suo controllo in cassazione. Milano: Giuffrè, 1997. p. 12. (tradução livre). 
Khaled Jr., "há uma exigência de fundo cognitivo a qual o juiz deve corresponder”, pois ele "não dispõe de discricionariedade absoluta quanto ao acolhimento das representações narrativas que são introduzidas no processo"22.

Em contraposição à teoria cognitivo-racional, visão distinta sobre a função das provas no processo penal centraliza sua construção na figura do julgador e de suas determinantes no desenrolar do caso penal. Afirma-se que "as provas são materiais que permitem a reconstrução histórica e sobre os quais recai a tarefa de verificação das hipóteses, com a finalidade de convencer o juiz (função persuasiva)"23. Assumindo um caráter eminentemente narrativo e discursivo, a prova se dirige à "captura psíquica" do julgador ${ }^{24}$. Ou seja, nesse sentido "a atividade probatória move-se pela intenção das partes de serem (a)creditadas em suas hipóteses”25. Em resumo, “a prova não seria um instrumento para conhecer racionalmente algo, mas um argumento persuasivo dirigido a fazer crer algo sobre os fatos relevantes para a decisão"26.

Por certo, na sentença, o juiz não revela a verdade dos fatos, como se isso fosse a sua missão no campo processual, tendo em vista as limitações desse conceito e a potencial abertura a espaços de arbitrariedades, a partir da postura ativa do julgador em sua busca. Contudo, por outro lado, também não se pode aceitar que nesse ato ele "constrói a 'sua' história do delito, elegendo os significados que the parecem válidos, dando uma demonstração inequívoca de crença, de fé”27. Tal postura finda por deslocar o ato de julgar para margens de extrema discricionariedade e subjetivismo, assim estruturando um campo de impossível controle e limitação ${ }^{28}$. Segundo Salah Khaled Jr., crítico à ideia da verdade no processo penal:

22 KHALED JR., Salah H. A busca da verdade no processo penal. Para além da ambição inquisitorial. São Paulo: Atlas, 2013. p. 551.

23 LOPES JR., Aury. Direito Processual Penal. 9a ed. São Paulo: Saraiva, 2012. p. 537.

${ }^{24}$ CORDERO, Franco. Procedimiento Penal. Vol. II. Santa Fe de Bogotá: Temis, 2000. p. 16; ARAGONESES ALONSO, Pedro. Instituciones de Derecho Procesal Penal. 3. ed. Madrid: Rubi, 1981. p. 283.

${ }^{25}$ MAYA, André M.; URANI, Marcelo F. 0 princípio da identidade física do juiz e a função persuasiva da prova no processo penal. In: FAYET JR., Ney; MAYA, André M. (orgs.). Ciências penais e sociedade complexa II. Porto Alegre: Nuria Fabris, 2009. p. 40.

26 TARUFFO, Michele. La prueba de los hechos. 4. ed. Madrid: Trotta, 2011. p. 350 (tradução livre).

27 LOPES JR., Aury. Direito Processual Penal. 9. ed. São Paulo: Saraiva, 2012. p. 575

${ }^{28}$ Considerando os riscos da posição assumida, Lopes Jr. argumenta que não se pode incidir no erro de um relativismo absurdo, propondo que o "respeito às regras do jogo cria condições de possibilidade para o equilíbrio entre o relativismo cético e a mitológica verdade real" (LOPES JR., Aury. Direito Processual Penal. 9. ed. São Paulo: Saraiva, 2012. p. 577). Pensa-se, contudo, que o respeito às regras do devido processo penal, fundamental e primordial, não supre a necessidade de controle e limitação à decisão judicial. $\mathrm{O}$ fato de que o processo se desenvolveu com a devida atenção às garantias e direitos do acusado não é suficiente para assegurar a correta valoração do lastro probatório produzido. A decisão do juiz precisa se pautar por critérios racionais e objetivos, pois somente assim se torna controlável (por ex. a partir do recurso sobre a condenação). 0 fato de o juiz estar convencido e aceitar uma das versões 
Não há como fugir da constatação de que a expulsão completa da verdade mataria a própria noção de motivação, o que com certeza seria conducente à maximização dos espaços potestativos de discricionariedade, algo absolutamente contrário aos propósitos de contenção regrada do poder punitivo. ${ }^{29}$

Por óbvio, na perspectiva das partes, o convencimento do julgador é um objetivo central para a obtenção de um resultado processual positivo. Isso é um dado de realidade inafastável e inerente ao jogo processual, que deve ser considerado ${ }^{30}$. Tal elemento, porém, não pode ser uma justificativa teórica aceitável para a fundamentação da decisão judicial e da valoração probatória na dogmática processual penal ${ }^{31}$. Geralmente, o fato de o juiz estar convencido é condição prática para a determinação da decisão, mas não é justificação legítima de seu conteúdo. Nas palavras de Gustavo Badaró, “o convencimento psicológico do juiz é uma condição necessária, mas não suficiente"32.

A visão persuasiva da prova é, assim, indispensável para a devida compreensão da lógica do processo penal, mas não fornece elementos para guiar a valoração probatória que deve ser realizada pelo julgador para a tomada da decisão sobre os fatos. É inquestionável que as partes produzem as provas para buscar o convencimento do juiz, mas quando, como e por que ele poderá se considerar “convencido"? Aqui somente há espaço para critérios objetivos e racionais, que fogem ao âmbito da sua possível contribuição teórica. Segundo Michele Taruffo:

A persuasão (como a não-persuasão) é um fato empírico sobre a situação subjetiva de alguém (no que aqui importa, do juiz), enquanto que, por outro lado, a teoria da prova é prescritiva na medida em que se refere a critérios de

apresentadas pelas partes não supre a necessidade de um controle intersubjetivo da decisão e isso só é possível a partir de uma conexão instrumental com a realidade, ou seja, a decisão do juiz somente é controlável se for aceito que ela deve ser a descrição mais provável dos fatos imputados (ou além da dúvida razoável, para a condenação penal).

${ }^{29}$ KHALED JR., Salah H. A busca da verdade no processo penal. Para além da ambição inquisitorial. São Paulo: Atlas, 2013. p. 550-551.

30 ROSA, Alexandre Morais da. Guia Compacto do Processo Penal conforme a Teoria dos Jogos. 3. ed. Florianópolis: Empório do Direito, 2016. p. 27-30.

31 “(...) é inegável que fatores persuasivos ou retóricos existem na formação das provas em juízo. Contudo, o problema não é estabelecer se esses fatores existem, mas decidir se são importantes para justificar uma teoria 'retórica' da prova que possa ser assumida como dominante ou, inclusive, como teoria exclusiva e única da prova" (TARUFFO, Michele. La prueba de los hechos. 4a ed. Madrid: Trotta, 2011. p. 350) (tradução livre). Sobre isso, também em: TARUFFO, Michele. Ermeneutica, prova e decisione. Revista Brasileira de Direito Processual Penal, Porto Alegre, vol. 4, n. 1, p. 129-148, jan./abr. 2018. p. 133-135. Disponível em: <https://doi.org/10.22197/rbdpp.v4i1.136>. Acesso em: 19 ago. 2018.

${ }^{32}$ BADARÓ, Gustavo Henrique. Processo Penal. 2. ed. Rio de Janeiro: Elsevier, 2014. p. 262. 
aceitabilidade e validade do raciocínio com o qual o juiz determina os fatos a partir das provas. ${ }^{33}$

A decisão do juiz precisa se pautar por critérios racionais e objetivos, pois somente assim se torna controlável (por ex. a partir do recurso sobre a condenação) ${ }^{34}$. 0 fato de o juiz estar convencido e aceitar uma das versões apresentadas pelas partes não supre a necessidade de um controle intersubjetivo da decisão e isso só é possível a partir de uma conexão instrumental com a realidade, ou seja, a decisão do juiz somente é controlável se for aceito que ela deve ser a descrição mais provável dos fatos imputados (ou além da dúvida razoável, para a condenação penal) $)^{35}$.

Diante das contribuições e deficiências expostas em relação às duas visões, sustenta-se neste artigo a tese de que a função da prova no processo penal deve ser analisada em seu duplo aspecto, tanto como instrumento cognitivo de reconstrução do fato passado, como elemento de persuasão do julgador em busca de seu convencimento. Uma postura não pode excluir a outra, em realidade, elas devem se complementar e se limitar reciprocamente.

Por um lado, o extravasamento da função cognitiva da prova tende a supervalorizar o papel da verdade no processo, tornando-a um instrumento exorbitantemente voltado ao seu descobrimento. Nesse cenário, abrem-se inevitáveis brechas para abusos de poder, especialmente em razão do incremento de poder do julgador ${ }^{36}$. Em razão da crença em um

33 TARUFFO, Michele. La prueba de los hechos. 4. ed. Madrid: Trotta, 2011. p. 355 (tradução livre). Em oposição à visão de Taruffo, Maya e Urani afirmam que a sua crítica "perde consistência na medida em que, através da motivação das decisões, é possível o controle sobre quais provas foram efetivamente persuasivas e quais não foram" (MAYA, André M.; URANI, Marcelo F. O princípio da identidade física do juiz e a função persuasiva da prova no processo penal. In: FAYET JR., Ney; MAYA, André M. (orgs.). Ciências penais e sociedade complexa II. Porto Alegre: Nuria Fabris, 2009. p. 44). Contudo, a existência da motivação não é suficiente, se não for possível o seu controle. Não basta a indicação pelo juiz dos elementos considerados persuasivos, é indispensável que haja a possibilidade de uma revisão a partir de critérios objetivos e racionais, em que se mostra necessária uma conexão instrumental com a realidade, onde a reconstrução cognitiva dos fatos passados é condição ao processo penal.

${ }^{34}$ FERNÁNDEZ LÓPEZ, Mercedes. Prueba y presunción de inocencia. Madrid: lustel, 2005. p. 238.

35 O conceito de "dúvida razoável" é intensamente discutido em âmbito doutrinário e jurisprudencial, fomentando inúmeros questionamentos que carecem de estudos específicos, fugindo às pretensões deste artigo. Assim, remete-se, exemplificativamente, a: FERRUA, Paolo. La prova nel processo penale. Revista Brasileira de Direito Processual Penal, Porto Alegre, vol. 4, n. 1, p. 81-128, jan./mai. 2018. p. 110-118. Disponível em: <https://doi.org/10.22197/rbdpp.v4i1.130>. Acesso em: 19 ago. 2018; CATALANO, Elena M. Ragionevole dubbio e logica della decisione. Milano: Giuffrè. 2016.

${ }^{36}$ KHALED JR., Salah H. A busca da verdade no processo penal. Para além da ambição inquisitorial. São Paulo: Atlas, 2013. p. 169. Sobre a relação entre o papel do julgador, os seus poderes instrutórios e os sistemas processuais, ver: VASCONCELLOS, Vinicius G. O 'Sistema Acusatório' do Processo Penal Brasileiro: Apontamentos Acerca do Conteúdo da Acusatoriedade a partir de Decisões do Supremo Tribunal Federal. Direito, Estado e Sociedade, n. 47, p. 181-204, jul./dez. 2015. Disponível em: <https://doi.org/10.17808/des.47.604>. Acesso em: 19 ago. 2018. 
falacioso mito ${ }^{37}$, o juiz finda por sair de sua posição passiva/garantidora para assegurar que 0 processo alcance seu objetivo de buscar a verdade, ao passo que a dúvida gerará um estado de pendência dificilmente aceitável ${ }^{38}$.

Tal visão apresenta insuficiências, pois desconsidera as limitações da pretensão de racionalidade da modernidade ${ }^{39}$ e dos inevitáveis espaços de discricionariedade subjetiva do ato de julgar, já que o magistrado, como ser-no-mundo, carrega consigo pré-compreensões e sua historicidade $^{40}$. A função persuasiva da prova, portanto, aporta o "dado de realidade" ao estudo da teoria probatória, visto que considera as determinantes pessoais do juiz que podem guiar a tomada a decisão. Embora tais elementos não se mostrem legítimos e suficientes para embasar o fundamento da prova, eles são circunstâncias que precisam ser sopesadas para permitir a devida compreensão das relações inerentes ao campo jurídico-penal.

Por outro lado, a função persuasiva da prova como meio de captação do convencimento do juiz tende a fortalecer uma interpretação abusivamente subjetiva da valoração probatória realizada pelo julgador ${ }^{41}$. Isso inviabilizaria, inclusive, a estruturação do regime recursal como controle da decisão judicial, ao passo que, obtido o convencimento do juízo a quo, mostra-se destoante a possibilidade de revisão por outro julgador.

A prova no processo penal, portanto, apresenta tal dupla função, em um sentido de relação simbiótica de autolimitação. Em razão do excesso de subjetivismo, que torna incontrolável o ato de julgar como mero convencimento persuadido, é necessário que se

${ }^{37}$ CASARA, Rubens R. R. Mitologia Processual Penal. São Paulo: Saraiva, 2015. p. 165-180.

38 Nesse sentido, embora apresente diversas contribuições pertinentes, Nieva Fenoll adota posição questionável, a partir de leitura da função cognitiva da prova e da busca da verdade no processo penal, ao sustentar que a dúvida deve ser evitada pelo julgador, adotando postura ativa na busca de provas, de modo que 0 in dubio pro reo deve ser uma alternativa excepcional e rigidamente subsidiária (NIEVA FENOLL, Jordi. La duda en el proceso penal. Madrid: Marcial Pons, 2013. p. 127-128). Pensa-se, contudo, que a adoção de postura ativa pelo julgador acarreta potenciais prejuízos à sua imparcialidade, abrindo indevidas brechas para abusividades e arbitrariedades. Nesse sentido, mostra-se acertada a afirmação de Khaled Jr. no sentido de que "a maquiagem conceitual da busca da verdade sob o caráter matizado, relativo ou aproximativo acaba fundamentando a continuidade da estrutura inquisitória de forma velada, subvertendo o caráter democrático exigível a um processo respeitoso dos direitos fundamentais do acusado" (KHALED JR., Salah H. A busca da verdade no processo penal. Para além da ambição inquisitorial. São Paulo: Atlas, 2013. p. 184).

${ }^{39}$ GAUER, Ruth C. Conhecimento e aceleração (mito, verdade e tempo). In: GAUER, Ruth C. (org.). A qualidade do tempo: para além das experiências históricas. Rio de Janeiro: Lumen Juris, 2004. p. 6; LOPES JR., Aury. Direito Processual Penal. 9. ed. São Paulo: Saraiva, 2012. p. 570.

40 KHALED JR., Salah H. A busca da verdade no processo penal. Para além da ambição inquisitorial. São Paulo: Atlas, 2013. p. 223; FERRAJOLI, Luigi. Direito e Razão. Teoria do Garantismo Penal. 4. ed. São Paulo: RT, 2014. p. 58

${ }^{41}$ MAYA, André M.; URANI, Marcelo F. O princípio da identidade física do juiz e a função persuasiva da prova no processo penal. In: FAYET JR., Ney; MAYA, André M. (orgs.). Ciências penais e sociedade complexa II. Porto Alegre: Nuria Fabris, 2009. p. 41-42. 
estabeleça uma ligação cognitiva entre os fatos e a decisão. Esta ligação, considerando as limitações da busca da verdade no processo, determinará que o convencimento judicial deverá se realizar por meio de critérios racionais juridicamente legítimos, que devem ser expressados na motivação da decisão ${ }^{42}$.

Por óbvio, o percurso mental do julgador e os reais motivos que podem ser considerados para a tomada da decisão são efetivamente incontroláveis, mas a necessidade de apresentação racional e juridicamente legítima na motivação impõe, ao menos, a consideração correlata de tais critérios aceitáveis. Segundo Salah Khaled Jr., a ideia de que a atividade probatória tem como objetivo a formação da convicção do julgador parte do pressuposto de que haja "uma hipótese sustentada pelas partes a partir de um fundo probatório, que tem como referencial a intenção de convencimento sobre a verdade e sobre a qual ela obrigatoriamente deve assentar, a partir de rastros análogos ao evento passado"43.

\section{MODELOS DE VALORAÇÃO PROBATÓRIA E SEU CONTROLE POR MEIO DE RECURSOS}

Assentadas as premissas assumidas em relação à função da prova no processo penal, deve-se partir para a análise dos modelos de valoração possíveis à decisão judicial sobre os fatos. Trata-se de temática intimamente relacionada às possibilidades de controle da decisão judicial, ao passo que, conforme o sistema variar entre os extremos do subjetivismo da convicção do juiz à rigidez dos critérios legais previamente fixados, haverá impacto direto na viabilidade de reexame do julgamento por juízo distinto.

Sem pretensões de uma reconstrução histórica linear ${ }^{44}$, costuma-se afirmar que um primeiro sistema de valoração probatória se determinou pelos denominados "juízos divinos" ou ordálias, a partir de uma lógica pautada pela irracionalidade da atuação judicial na resolução dos conflitos sociais ${ }^{45}$. Em tal panorama, "a verdade sobre o fato criminal se persegue apelando

\footnotetext{
42 BADARÓ, Gustavo Henrique. Processo Penal. 2. ed. Rio de Janeiro: Elsevier, 2014. p. 265.

${ }^{43}$ KHALED JR., Salah H. A busca da verdade no processo penal. Para além da ambição inquisitorial. São Paulo: Atlas, 2013. p. 404.

${ }^{44}$ Nieva Fenoll, por exemplo, afirma que, por uma questão de lógica, o primeiro sistema de valoração precisa ser o da liberdade do julgador, pois somente em reação a ele é que surgiram os demais, visando à limitação da discricionariedade do juiz (NIEVA FENOLL, Jordi. La valoración de la prueba. Madrid: Marcial Pons, 2012. p. 40).

45 GOMES FILHO, Antonio Magalhães. Direito à prova no processo penal. São Paulo: RT, 1997. p. 20; AMORIM, Guilherme Freitas. Os controles de racionalidade na valoração da prova no processo penal.
} 
a força sobrenaturais; por isso as provas são buscadas e operam à margem do fato objeto da investigação" ${ }^{46}$. Determinava-se, por exemplo, que o réu seria inocente se caminhasse sobre brasas incandescentes ou mergulhasse em água fervente sem sofrer lesões ou tomava-se como vitoriosa a parte que não fosse morta por um leão ao ser jogada na sua jaula ${ }^{47}$. Diante da irracionalidade do mecanismo e da dissociação entre o fato a ser provado e o critério utilizado para a decisão, Nieva Fenoll afirma que ele, em realidade, "não é um meio de prova, nem um sistema de valoração da prova, mas supõe, em realidade, a completa anulação da referida valoração"48.

$\mathrm{Na}$ descrição de Andrés Ibañez, a partir da concentração dos poderes no monarca e o avanço na oficialização da persecução penal, as ordálias foram progressivamente afastadas, o que findou por sua proibição no período da Inquisição Católica com o IV Concílio de Latrão ${ }^{49}$. Em seu lugar, ocupa a primazia na valoração probatória o sistema das provas legais, em que não o julgador, mas o legislador de um modo prévio e abstrato define o resultado probatório de cada meio de prova ${ }^{50}$. Diante disso, a doutrina discute se tal determinação prévia necessariamente ocorria em sede normativa, pois há quem aponte que, em realidade, tratou-se de uma construção fundamentalmente doutrinária, que, por reflexo, teve impacto nas legislações da época ${ }^{51}$.

A lógica das provas legais restringia ao máximo a discricionariedade subjetiva do magistrado na determinação do juízo fático no caso concreto, pois fixava previamente os requisitos para que um fato pudesse (ou necessariamente devesse) ser considerado verdadeiro no processo. Por exemplo, era necessário o relato de duas testemunhas para determinar a veracidade do ocorrido, pois nunca era suficiente a versão de uma $\operatorname{apenas}^{52}$. Diante das dificuldades para cumprimento de tais condições, houve um fortalecimento da busca pela confissão do acusado, que era considerada uma prova plena e inquestionável, o que autorizou a

Revista de Estudos Criminais, Porto Alegre, v. 10, n. 36, p. 159-182, jan./mar. 2010. p. 161; TARUFFO, Michele. La prueba de los hechos. 4. ed. Madrid: Trotta, 2011. p. 387.

46 ANDRÉS IBÁÑ̃EZ, Perfecto. Prueba y convicción judicial en el proceso penal. Buenos Aires: Hammurabi, 2009. p. 28 (tradução livre).

47 GASCÓN ABELLÁN, Maria. Los hechos en el derecho. Bases argumentales de la prueba. 3. ed. Madrid: Marcial Pons, 2010. p. 13; ALMEIDA JÚNIOR, João Mendes de. O processo criminal brazileiro. Vol. 1. 4. ed. Rio de Janeiro: Batista de Souza, 1920. p. 53.

${ }^{48}$ NIEVA FENOLL, Jordi. La valoración de la prueba. Madrid: Marcial Pons, 2012. p. 41 (tradução livre).

49 ANDRÉS IBÁÑEZ, Perfecto. Prueba y convicción judicial en el proceso penal. Buenos Aires: Hammurabi, 2009. p. 30.

50 FERRER BELTRÁN, Jordi. La valoración racional de la prueba. Madrid: Marcial Pons, 2007. p. 62; ALMEIDA, Vitor L. A apreciação judicial da prova nos sistemas de valoração. Jurisprudência Mineira, Belo Horizonte, v. 65, n. 208, p. 27-33, jan./mar. 2014. p. 28.

51 TARUFFO, Michele. La prueba de los hechos. 4a ed. Madrid: Trotta, 2011. p. 389.

52 GOMES FILHO, Antonio Magalhães. Direito à prova no processo penal. São Paulo: RT, 1997. p. 24. 
utilização corriqueira da tortura ${ }^{53}$. Segundo Gascón Abellar, o sistema de prova legal manteve o elemento fundamental da lógica anterior das ordálias, pois se constituíam como exemplos de "provas formais", em que se substitui a investigação do caso por um juízo pretensamente infalivel e superior ${ }^{54}$.

Em relação à revisão recursal, pode-se afirmar que o sistema de provas legais se encaixava adequadamente em um panorama de facilitação ao controle burocrático e à concentração de poderes, pois permitia o reexame por julgador superior sem maiores dificuldades. Ao reduzir profundamente os espaços de efetiva valoração da prova e tornar tal ato uma mera verificação de atenção às quantidades e espécies de elementos necessários para a condenação, autorizava a revisão sem qualquer questionamento no que diz respeito ao contato do julgador ad quem com a produção da prova.

Diante das arbitrariedades ocasionadas para obtenção de confissões e o desvelamento da manutenção de premissas irracionais na valoração probatória ${ }^{55}$, percebeu-se que o sistema deveria permitir a “observação direta e crítica dos fatos”, em uma resposta fundamentada em pensamentos iluministas, de modo que os resultados das provas "deveriam ser submetidos à livre apreciação dos julgadores, sem apriorismo consubstanciado nas regras de avaliação aritmética das provas" ${ }^{26}$. Assim, consagrou-se o sistema da livre convencimento, caracterizado pela ausência de regras legais, impondo que "a eficácia de cada prova para a determinação dos fatos seja estabelecida caso a caso, seguindo critérios não predeterminados, discricionários e flexíveis, baseados essencialmente em pressupostos racionais" ${ }^{27}$.

Embora a doutrina apresente certas imprecisões, em geral, partindo-se da premissa da inexistência de critérios abstrata e previamente definidos para a valoração da prova, pode-se classificar os sistemas de livre convencimento em dois modelos: íntima convicção e valoração racional motivada ${ }^{58}$. Fundamentalmente inspirado no panorama dos julgamentos por jurados,

53 AMORIM, Guilherme Freitas. Os controles de racionalidade na valoração da prova no processo penal. Revista de Estudos Criminais, Porto Alegre, v. 10, n. 36, p. 159-182, jan./mar. 2010. p. 163.

${ }^{54}$ GASCÓN ABELLÁN, Maria. Los hechos en el derecho. Bases argumentales de la prueba. 3. ed. Madrid: Marcial Pons, 2010. p. 14.

55 NIEVA FENOLL, Jordi. La valoración de la prueba. Madrid: Marcial Pons, 2012. p. 69.

56 GOMES FILHO, Antonio Magalhães. Direito à prova no processo penal. São Paulo: RT, 1997. p. 26.0 autor, contudo, afirma que há certa contradição na visão iluminista, pois, embora clamasse por critérios de estrita legalidade em relação aos delitos e às penas, pugnava a liberdade do julgador na valoração das provas (Ibidem, idem).

57 TARUFFO, Michele. La prueba de los hechos. 4. ed. Madrid: Trotta, 2011. p. 387 (tradução livre).

58 AMORIM, Guilherme Freitas. Os controles de racionalidade na valoração da prova no processo penal. Revista de Estudos Criminais, Porto Alegre, v. 10, n. 36, p. 159-182, jan./mar. 2010. p. 167. 0 sistema de "valoração racional motivada" também é denominado "persuasão racional” ou "livre convencimento motivado", contudo opta-se pela primeira definição para evitar eventuais confusões, pois "persuasão 
cuja manifestação mais clara ocorreu no Código francês de 1808, a íntima convicção significa a “liberdade total para quem julga na hora de apreciar as provas, sem necessidade de motivar a decisão, mas dentro da 'sinceridade de sua consciência'"59. Tal lógica é adotada pelo ordenamento criminal brasileiro nas hipóteses de julgamento pelo procedimento do Júri, em que os juízes leigos respondem a quesitos somente indicando "sim" ou "não", sem qualquer necessidade de fundamentação ${ }^{60}$.

No que diz respeito à possibilidade de reexame da decisão em âmbito recursal, a ausência de motivação e a dependência à consciência do julgador inviabilizam a efetividade da revisão sobre a valoração probatória, esvaziando o controle da decisão em aspectos essenciais. Se houver o cabimento de reexame, no máximo estar-se-ia substituindo uma convicção íntima por outra, sem qualquer controle racional sobre o juízo fático realizado. Assim, deve-se questionar a compatibilidade de tal sistema com um processo penal pautado pelos ditames do Estado Democrático de Direito. A imposição de uma sanção penal sem a devida justificação inevitavelmente deslegitima a atuação estatal, abrindo espaços indevidos para discriminações e arbitrariedades na decisão jurisdicional ${ }^{61}$.

Por outro lado, espécie distinta do livre convencimento é a valoração racional motivada. Trata-se de sistema em que o julgador não resta vinculado a critérios prévios e abstratos, possuindo, portanto, liberdade na valoração da prova. Precisa, entretanto, fundamentar a sua decisão, apresentando os motivos que determinaram a consideração de um ou outro fato como verdadeiro62. Segundo Gascón Abellán, “a valoração da prova deve ser concebida como uma atividade racional caracterizada pela eleição da hipótese mais provável entre as diversas reconstruções possíveis" ${ }^{63}$, ou, no processo penal, proferindo a condenação somente se não houver dúvida razoável sobre a tese acusatória.

racional" se assemelha a uma das teorias sobre a função da prova estudadas anteriormente, e "livre convencimento" é mais adequado para caracterizar o gênero, cujas espécies são a "íntima convicção" e a "valoração racional motivada".

${ }^{59}$ NIEVA FENOLL, Jordi. La valoración de la prueba. Madrid: Marcial Pons, 2012. p. 74 (tradução livre).

${ }^{60}$ BADARÓ, Gustavo Henrique. Processo Penal. 2. ed. Rio de Janeiro: Elsevier, 2014. p. 291.

${ }^{61}$ VASCONCELLOS, Vinicius G.; GALÍCIA, Caíque R. Tribunal do Júri na Justiça Criminal Brasileira: críticas e propostas de reforma para a restituição de sua função de garantia no processo penal democrático. Revista Eletrônica de Direito Processual, Rio de Janeiro, vol. XIII, p. 903-929, jan./jun. 2014. p. 909-914; SANTOS, André Leonardo Copetti. A Incompatibilidade das Decisões do Conselho de Sentença do Tribunal do Júri com o Estado Democrático de Direito: uma interpretação da legitimidade das decisões judiciais a partir de uma interseção entre filosofia e direito. Sistema Penal \& Violência, Porto Alegre, vol. 3, n. 1, p. 30-46, jan./jun. 2011. p. 41.

62 TARUFFO, Michele. Consideraciones sobre prueba y motivación. Jueces para la democracia. Madri, v. 59, p. 71-79, jul. 2007. p. 73.

${ }^{63}$ GASCÓN ABELLÁN, Maria. Los hechos en el derecho. Bases argumentales de la prueba. 3. ed. Madrid: Marcial Pons, 2010. p. 144 (tradução livre). 
Essa é a postura comumente aceita pela doutrina como regra adotada no ordenamento brasileiro, em que vige o denominado "livre convencimento motivado" ${ }^{64}$. Para evitar indevidas compreensões que pugnem por uma inaceitável e incontrolável discricionariedade, porém, pensa-se que tal terminologia é inadequada, ao ressaltar uma liberdade do julgador. Assim, mostra-se preferível excluir o termo "livre" ${ }^{65}$, adotando-se a denominação aqui sustentada: "valoração racional motivada".

Em relação às possibilidades recursivas, se adotada uma visão racional da livre valoração, a doutrina afirma que se consolida uma inerente necessidade de controle pela via impugnativa. ${ }^{66}$ Conforme Del Río Ferreti, na lógica do modelo cognitivo racional:

O recurso não é um meio para substituir uma valoração íntima e subjetiva por outra semelhante, mas meio para verificar a racionalidade do juízo como resultado da valoração da prova ou, na hipótese do segundo grau (apelação), uma forma de substituir uma valoração comprovadamente incorreta. ${ }^{67}$

Diante das visões apresentadas, percebe-se que leituras indevidas de ambos os sistemas apresentam potenciais problemas à necessária lógica de limitação do poder punitivo que deve determinar o direito processual penal ${ }^{68}$. Assim, nas palavras de Francesco lacoviello:

O processo corre um duplo risco: de implosão, se provas legais, preconceitos culturais e pressões ocultas comprimirem a autodeterminação do juiz; de explosão, se a liberdade decisória do julgador não sofrer qualquer limitação à sua expansão. ${ }^{69}$

A tendência ao abuso, característica ao exercício do poder punitivo, manifesta-se em leituras arbitrárias do "livre convencimento", as quais extrapolam a suposta liberdade do

\footnotetext{
${ }^{64}$ MENDES, Regina Lúcia Teixeira. Do Princípio do Livre Convencimento Motivado. Legislação, doutrina e interpretação de juízes brasileiros. Rio de Janeiro: Lumen Juris, 2011. p. 22-30; HARTMANN, Érica O. Os sistemas de avaliação da prova e o processo penal brasileiro. Revista da Faculdade de Direito UFPR, Curitiba, v. 39, p. 109-123, 2003. p. 118. Disponível em: <https://doi.org/10.5380/rfdufpr.v39i0.1749>. Acesso em: 19 ago. 2018.

${ }^{65}$ AMORIM, Guilherme Freitas. Os controles de racionalidade na valoração da prova no processo penal. Revista de Estudos Criminais, Porto Alegre, v. 10, n. 36, p. 159-182, jan./mar. 2010. p. 160.

${ }^{66}$ FERRER BELTRÁN, Jordi. La valoración racional de la prueba. Madrid: Marcial Pons, 2007. p. 66; BADARÓ, Gustavo Henrique. Manual dos Recursos Penais. São Paulo: RT, 2016. p. 55

67 FERRETI, Carlos del Río. Estudio sobre el derecho al recurso en el proceso penal. Estudios Constitucionales, ano 10, n. 01, p. 245-288, 2012. p. 250 (tradução livre). Disponível em: <https://doi.org/10.4067/s0718-52002012000100007>. Acesso em: 19 ago. 2018.

68 SALAVERRIA, Juan. Valoración de la prueba, motivación y control en el proceso penal. Valencia: Tirant lo Blanch, 1995. p. 77.

69 IACOVIELLO, Francesco M. La motivazione della sentenza penale e il suo controllo in cassazione. Milano: Giuffrè, 1997. p. 65 (tradução livre).
} 
julgador ao valorar as provas, adotando um subjetivismo exacerbado e esvaziando o dever de motivação da decisão ${ }^{70}$. Segundo Michele Taruffo, "o uso degenerativo que às vezes se faz desse princípio abre caminho para a legitimação da arbitrariedade subjetiva do juiz ou, no melhor dos casos, a uma discricionariedade que não se submete a critérios e pressupostos"71.

A necessária superação do sistema de provas legais, que inquestionavelmente ocasiona aporias ao processo decisório, pela livre convicção se caracterizou como "uma das páginas politicamente mais amargas e intelectualmente mais deprimentes da histórica das instituições penais"72. Nesse cenário, a valoração da prova pelo julgador findou por se transformar em um “momento místico"73, em que leituras abusivas do princípio da imediação determinam que o juiz precisa ter um contato direto com a prova no momento de sua produção para poder perceber elementos subjetivos, emocionais e irracionais, não relacionados aos fatos imputados, e, portanto, não controláveis intersubjetivamente ${ }^{74}$.

Diante de tais aporias, é primordial ressaltar que a liberdade na "valoração racional motivada" representa somente a ausência de critérios previa e abstratamente definidos que vinculem o julgador e excluam a valoração específica no caso concreto, mas de nenhum modo permite uma completa discricionariedade na tomada da decisão ${ }^{75}$. Por certo, essa premissa já é essencial, mas igualmente resta inegável que a doutrina processual penal ainda tem muito a construir para estruturar uma verdadeira teoria da valoração da prova, com critérios objetivos, racionais e controláveis ${ }^{76}$.

\footnotetext{
70 SALAVERRIA, Juan. Valoración de la prueba, motivación y control en el proceso penal. Valencia: Tirant lo Blanch, 1995. p. 36.

71 TARUFFO, Michele. La prueba de los hechos. 4. ed. Madrid: Trotta, 2011. p. 398 (tradução livre).

72 FERRAJOLI, Luigi. Direito e Razão. Teoria do Garantismo Penal. 4. ed. São Paulo: RT, 2014. p. 133. Assim também: STRECK, Lenio Luiz. A filosofia traída pela dogmática jurídica: uma crítica à noção de verdade e ao livre convencimento no processo penal. In: MALAN, Diogo; MIRZA, Flávio (coord.). 70 anos do Código de Processo Penal brasileiro. Balanço e perspectivas de reforma. Rio de Janeiro: Lumen Juris, 2011. p. 240-248.

73 ANDRÉS IBÁÑEZ, Perfecto. Acerca de la motivación de los hechos en la sentencia penal. Doxa: Cuadernos de Filosofia del Derecho, n. 12, p. 257-299, 1992. p. 280 (tradução livre). Assim também: GASCÓN ABELLÁN, Maria. Los hechos en el derecho. Bases argumentales de la prueba. 3. ed. Madrid: Marcial Pons, 2010. p. 34.

${ }^{74}$ ANDRÉS IBÁÑNEZ, Perfecto. Sobre el valor de la inmediación (una aproximación crítica). Jueces para la democracia, n. 46, p. 57-66, mar. 2000. p. 64.

75 FERRER BELTRÁN, Jordi. La valoración racional de la prueba. Madrid: Marcial Pons, 2007. p. 45; LLORENTE SÁNCHEZ-ARJONA, Mercedes. La segunda instancia en el proceso penal. Doctrina y jurisprudencia. Granada: Comares, 2000. p. 137; KNIJNIK, Danilo. A prova nos juízos cível, penal e tributário. Rio de Janeiro: Forense, 2007. p. 16. Sobre isso: STRECK, Lenio L. O que é isto - decido conforme a minha consciência? 4. ed. Porto Alegre: Livraria do Advogado, 2013. p. 105-120.

${ }^{76}$ NIEVA FENOLL, Jordi. La valoración de la prueba. Madrid: Marcial Pons, 2012. p. 24.
} 
A adoção da “livre convicção", a partir da superação das provas legais, até agora não passa de "um trivial princípio negativo" na descrição apresentada por grande parte dos autores $^{77}$. Conforme Michele Taruffo, "quando cai (nos limites em que isso ocorreu) o sistema da prova legal, ele não é substituído por uma nova racionalidade, mas pelo vazio"78. Ou seja, proibiu-se a determinação vinculante da valoração probatória de modo abstrato e prévio, afirmando-se que o julgador tem liberdade para analisar o lastro produzido no caso concreto, mas não foram previstos critérios para guiar essa atuação ${ }^{79}$.

Nesse sentido, para tornar possível o estabelecimento de uma teoria racional de valoração das provas e o fortalecimento do dever de motivação, o controle da decisão (especialmente pelo sistema recursal) é elemento indispensável para a estruturação da dogmática processual penal. Somente a partir do respeito a critérios objetivos, orientados pelas diretrizes constitucionais e convencionais ${ }^{80}$, e o reexame efetivo da condenação, como reforço da presunção de inocência e do direito de defesa, torna-se viável a determinação do processo penal como instrumento de limite ao poder punitivo.

\section{MODELOS DE VALORAÇÃO PROBATÓRIA E SEU CONTROLE POR MEIO DE RECURSOS}

A partir das premissas adotadas pelas visões expostas anteriormente, o problema da valoração probatória tem sido renegado por parte da doutrina e pela prática corriqueira nos tribunais. A crença na consciência subjetiva do julgador e em leituras abusivas da imediação como contato com elementos irracionais da produção da prova fundamenta posições de fortalecimento de uma suposta "intangibilidade da decisão de 10 grau sobre fatos" 81 . Diante disso, percebe-se a utilização de argumentos ancorados em uma pretensa impossibilidade de

\footnotetext{
77 Sobre isso: FERRAJOLI, Luigi. Direito e Razão. Teoria do Garantismo Penal. 4. ed. São Paulo: RT, 2014. p. 133; SALAVERRIA, Juan. Valoración de la prueba, motivación y control en el proceso penal. Valencia: Tirant lo Blanch, 1995. p. 32-33.

${ }^{78}$ TARUFFO, Michele. La prueba de los hechos. 4. ed. Madrid: Trotta, 2011. p. 396 (tradução livre).

${ }^{79}$ NIEVA FENOLL, Jordi. La valoración de la prueba. Madrid: Marcial Pons, 2012. p. 65-66.

80 MALAN, Diogo. Notas sobre a investigação e prova da criminalidade econômico-financeira organizada. Revista Brasileira de Direito Processual Penal, Porto Alegre, vol. 2, p. 213-238, 2016. Disponível em: <https://doi.org/10.22197/rbdpp.v2i1.22>. Acesso em: 19 ago. 2018.

81 FUENTES MAUREIRA, Claudio. Derecho a recurso y el estándar fijado en el fallo Herrera Ulloa: una lectura hacia su compatibilidad con los sistemas procesales penales acusatorios. Revista CEJIL, ano IV, n. 05, p. 74-82, dez. 2009. p. 75 (tradução livre). Sobre isso: FERNÁNDEZ LÓPEZ, Mercedes. Prueba y presunción de inocencia. Madrid: lustel, 2005. p. 234.
} 
revisão da valoração probatória em sede recursal em juízos de apelação, o que esvazia por completo a efetividade do direito ao recurso no processo penal ${ }^{82}$.

Por certo, tal visão tem inspiração em posições historicamente construídas (e superadas por parte da doutrina) que reduzem a complexidade do juízo fático na decisão judicial, afirmando que os fatos são autoevidentes a partir da simples observação das provas, de modo que inexistiria qualquer decisão valorativa em tal âmbito. Segundo Andrés Ibañez:

0 tratamento judicial que habitualmente recebem os fatos costuma refletir a sua consideração como entidades naturais, prévia e definitivamente constituídas desde o momento de sua produção, que somente se trataria de identificar em sua objetividade. ${ }^{83}$

Nesse sentido, o "mero juízo de fato" 84 não teria complexidade suficiente para necessitar de motivação e de controle em âmbito recursal ${ }^{85}$. Contudo, “o processo penal não vive em um mundo de verdades autoevidentes, que se manifestam no juízo público: a verdade não se mostra, mas se demonstra, por meio de argumentação racional"86. Por um lado, resta claro que a atuação do juiz no procedimento da prova influencia diretamente, tanto a produção, como a valoração do lastro probatório, que não se caracterizam como decisões imunes aos critérios adotados pelo julgador. Por certo, o juízo fático é elemento primordial da sentença penal, carecendo de efetivo controle por meio da esfera recursal. Em atenção a Gomes Filho, torna-se cristalino que é no juízo fático que "se manifesta com maior amplitude a discricionariedade judicial, o que deve ensejar, em consequências, um cuidado maior em relação ao seu controle" ${ }^{87}$.

82 LLORENTE SÁNCHEZ-ARJONA, Mercedes. La segunda instancia en el proceso penal. Doctrina y jurisprudencia. Granada: Comares, 2000. p. 137-146.

83 ANDRÉS IBÁÑEZ, Perfecto. Acerca de la motivación de los hechos en la sentencia penal. Doxa: Cuadernos de Filosofia del Derecho, n. 12, p. 257-299, 1992. p. 263 (tradução livre). Sobre isso também: ANDRÉS IBÁÑEZ, Perfecto. Prueba y convicción judicial en el proceso penal. Buenos Aires: Hammurabi, 2009. p. 47.

${ }^{84} \mathrm{Em}$ crítica a tal expressão: KHALED JR., Salah H. A busca da verdade no processo penal. Para além da ambição inquisitorial. São Paulo: Atlas, 2013. p. 224.

${ }^{85}$ GASCÓN ABELLÁN, Maria. Los hechos en el derecho. Bases argumentales de la prueba. 3. ed. Madrid: Marcial Pons, 2010. p. 12.

${ }^{86}$ IACOVIELLO, Francesco M. La motivazione della sentenza penale e il suo controllo in cassazione. Milano: Giuffrè, 1997. p. 9 (tradução livre).

${ }^{87}$ GOMES FILHO, Antonio Magalhães. A motivação das decisões penais. 2. ed. São Paulo: RT, 2013. p. 119. 
Além disso, a crença em um caráter autoevidente dos fatos reforça o seu poder alucinatório que inviabiliza a possibilidade do contraditório e do direito de defesa ${ }^{88}$. Conforme Cunha Martins:

[...] diz-se evidente o que dispensa a prova. Simulacro de auto-referencialidade, pretensão de uma justificação centrada em si mesmo, a evidência corresponde a uma satisfação demasiado rápida perante indicadores de mera plausibilidade. De alguma maneira, a evidência instaura um desamor do contraditório. ${ }^{89}$

Nesse sentido, o controle da decisão por meio do recurso é um elemento que fortalece o processo penal como instrumento de limite ao poder punitivo estatal ao se tornar meio de constrangimento à evidência90. Segundo Daniel Pastor, “a quaestio facti e seu tratamento na sentença constituem o exercício do poder penal por antonomásia"91. A gestão da prova e a sua valoração são manifestações de poder ${ }^{92}$, que precisam de limitação especialmente ocasionada pelo controle da decisão em âmbito recursal ${ }^{93}$, sob pena de completo esvaziamento da construção dogmática que se denomina "teoria da prova"

Nesse quadro, destaca-se a importância do controle sobre a decisão do juiz criminal, pois “é inútil obrigar o juiz a se submeter à lei se ele for livre para escolher os fatos sobre os

\footnotetext{
${ }^{88}$ Sobre a importância do contraditório e da participação das partes na tomada da decisão: ANDRADE, Flávio da Silva. A construção participada da decisão penal no Estado Democrático de Direito: a garantia de participação das partes, pelo contraditório, na composição da decisão justa e legítima. Revista Brasileira de Direito Processual Penal, Porto Alegre, vol. 3, n. 3, p. 1007-1041, set./dez. 2017.

${ }^{89}$ MARTINS, Rui Cunha. O Ponto Cego do Direito. The brazilian lessons. 2a ed. Rio de Janeiro: Lumen Juris, 2011. p. 03. Sobre isso, ver: AMARAL, Augusto J. Política da prova e cultura punitiva: a governabilidade inquisitiva do processo penal brasileiro contemporâneo. São Paulo: Almedina, 2014. p. 390-406.

90 Sobre a necessidade de constrangimento à evidência: KHALED JR., Salah H. A busca da verdade no processo penal. Para além da ambição inquisitorial. São Paulo: Atlas, 2013. p. 363-364.

91 PASTOR, Daniel R. La nueva imagen de la casación penal. Evolución histórica y futuro de la dogmática de la impugnación en el derecho procesal penal. Buenos Aires: Ad-Hoc, 2001. p. 56 (tradução livre).

92 ANDRÉS IBÁÑEZ, Perfecto. Prueba y convicción judicial en el proceso penal. Buenos Aires: Hammurabi, 2009. p. 28.

${ }^{93}$ GASCÓN ABELLÁN, Maria. Los hechos en el derecho. Bases argumentales de la prueba. 3. ed. Madrid: Marcial Pons, 2010. p. 178.

94 “A tese que sustentarei é que há um nexo lógico entre o controle sobre a lógica da prova, a carga da motivação e o dever do juiz, e o peso acusatório da prova. Em outras palavras, não há carga da prova nem, a rigor, necessidade da prova, se não existe a obrigação de motivar adequadamente; e essa obrigação é inconsistente se seu descumprimento não é submetido a um controle e a uma consequente invalidação." (FERRAJOLI, Luigi. Los valores de la doble instancia y de la nomofilaquia. Crimen y Castigo: Cuaderno del Departamento de Derecho Penal y Criminología de la Facultad de Derecho, Buenos Aires, v. 1, n. 1, p. 33-50, ago. 2001. p. 44) (tradução livre).
} 
quais vai decidir"95. Primeiramente, é fundamental reforçar o dever de motivação, que necessariamente deve abarcar de modo exaustivo o juízo fático tomado como base na decisão. Nas palavras de Michele Taruffo, "a motivação sobre os fatos é necessária, como a motivação sobre o direito aplicado, precisamente como garantia de racionalidade e de controlabilidade da valoração das provas" suficientes para um controle efetivo da sentença. É indispensável que exista mecanismo jurídico que permita a correção do erro com possibilidade de consequências concretas ao caso específico em análise ${ }^{97}$.

Assim, a hipótese de erro na valoração da prova é a causa recursal mais importante e genuína no sistema processual, pois possibilita o controle sobre os critérios utilizados pelo julgador a quo para aquilo que é a função principal do processo penal, verificar a imputação penal apresentada na acusação. Conforme Richard González, “a possibilidade de impugnar a valoração inicial do juiz a quo em relação à prova praticada constitui a essência do direito ao recurso no processo penal, especialmente em caso de sentença condenatória"98.

Partindo-se da premissa assentada anteriormente no sentido da necessidade de um sistema racional de valoração da prova, pautado por critérios objetivos e controláveis intersubjetivamente, a impugnação sobre o juízo fático determinado na sentença condenatória é um elemento potencializador da racionalidade do processo ${ }^{99}$. Aceitando-se a complexidade e a incerteza inerentes às situações processuais, deve-se potencializar os mecanismos de controle para reduzir, ao mínimo possível, o decisionismo no julgamento criminal ${ }^{100}$.

\footnotetext{
${ }^{95}$ HERBEL, Gustavo A. La motivación de la condena y su revisión amplia como garantías del imputado (¿puede el juicio por jurados restringirlas?). Revista de Derecho Penal y Procesal Penal, Buenos Aires, $n$. 4, p. 679-687, 2013. p. 684 (tradução livre).

96 TARUFFO, Michele. La prueba de los hechos. 4. ed. Madrid: Trotta, 2011. p. 434 (tradução livre).

97 GASCÓN ABELLÁN, Maria. Los hechos en el derecho. Bases argumentales de la prueba. 3. ed. Madrid: Marcial Pons, 2010. p. 179. Sobre a utilização da apelação para esse controle: SUAU MOREY, Jaime. Inmediación y Apelación en el Proceso Penal. Jurisprudencia TC y reformas procesales. Barcelona: JM Bosch, 2010. p. 122.

98 RICHARD GONZÁLEZ, Manuel. La impugnación y revisión de la prueba mediante los recursos ordinarios y extraordinarios en el proceso penal. In: LLUCH, Xavier Abel; GONZÁLEZ, Manuel Richard (Dir.). Estudios sobre prueba penal: actos de investigación y medios de prueba en el proceso penal: diligencias de instrucción, entrada y registro, intervención de comunicaciones, valoración y revisión de la prueba en vía de recurso. Madrid: La Ley, 2013. p. 427. Assim também: LÓPEZ ORTEGA, Juan J. El control de los hechos en el juicio de apelación. Jueces para la democracia, Madri, v. 66, p. 101-117, nov. 2009. p. 102.

99 FERRETI, Carlos del Río. Estudio sobre el derecho al recurso en el proceso penal. Estudios Constitucionales, ano 10, n. 01, p. 245-288, 2012. p. 250, nota 22 . Disponível em: <https://doi.org/10.4067/s0718-52002012000100007>. Acesso em: 19 ago. 2018.

100 KHALED JR., Salah H. A busca da verdade no processo penal. Para além da ambição inquisitorial. São Paulo: Atlas, 2013. p. 556.
} 
Logo, como reforço à presunção de inocência, o direito ao recurso sobre a condenação precisa possibilitar a fragilização da tese acusatória assumida pelo julgador a partir do lastro probatório produzido, verificando se realmente foi superada a dúvida razoável ${ }^{101}$. Ou seja, a impugnação deve permitir um "controle objetivo sobre a dúvida", a partir das razões apresentadas pela defesa para desestruturar a versão incriminatória firmada na sentença ${ }^{102}$. Segundo López Ortega, “o controle do standard probatório alcança sua máxima operatividade no recurso de apelação, especialmente porque constitui o marco processual adequado para verificar se existem outras inferências alternativas razoáveis"103.

\section{CONCLUSÃO}

Diante do exposto nesse artigo, retomam-se os problemas que guiaram o seu desenvolvimento: 1) qual a função da prova no processo penal?; 2) a decisão judicial sobre valoração das provas é livre?; e, 3) o juízo sobre os fatos na decisão judicial deve ser submetido a controle?

1. Diante das contribuições e deficiências expostas em relação às duas visões majoritárias sobre a função da prova no processo penal, sustenta-se neste artigo a tese de que ela deva ser analisada em seu duplo aspecto, tanto como instrumento cognitivo de reconstrução do fato passado como elemento de persuasão do julgador em busca de seu convencimento. Uma postura não pode excluir a outra, mas, em realidade, elas devem se complementar e limitar reciprocamente.

Por um lado, a visão cognitiva aporta contribuições ao ressaltar a importância de uma conexão instrumental com a realidade, para limitar o espaço decisório do juiz ao permitir um controle externo à motivação decisória, além de fundamentar as premissas epistemológicas da teoria da prova na dogmática processual penal. Tal postura, porém, tende a supervalorizar o

\footnotetext{
101 Sobre isso, ver: VASCONCELLOS, Vinicius G. Direito ao Recurso no Processo Penal: conteúdo e dinâmica procedimental de um modelo de limitação do poder punitivo estatal pelo controle efetivo da sentença condenatória. 2017. Tese (Doutorado em Direito) - Faculdade de Direito, Universidade de São Paulo, São Paulo. Em relação à importância e o conteúdo da presunção de inocência, ver: PRADO, Geraldo. Prova penal e sistema de controle epistêmicos. São Paulo: Marcial Pons, 2014. p. 17-18; FERRER BELTRÁN, Jordi. Uma concepção minimalista e garantista de presunção de inocência. Revista Brasileira de Direito Processual Penal, Porto Alegre, vol. 4, n. 1, p. 149-182, jan./abr. 2018. Disponível em: <https://doi.org/10.22197/rbdpp.v4i1.131>. Acesso em: 19 ago. 2018.

102 ALCÁCER GUIRAO, Rafael. El Derecho a una Segunda Instancia con Todas las Garantías. Valencia: Tirant lo Blanch, 2013. p. 106-107.

103 LÓPEZ ORTEGA, Juan J. El control de los hechos en el juicio de apelación. Jueces para la democracia, Madri, v. 66, p. 101-117, nov. 2009. p. 116 (tradução livre).
} 
papel da verdade no processo, abrindo brechas para abusos na proatividade do julgador, além de desconsiderar as limitações da pretensão de racionalidade da modernidade e dos inevitáveis espaços de discricionariedade subjetiva do ato de julgar.

A função persuasiva da prova, por outro lado, aporta o "dado de realidade" ao estudo da teoria probatória, visto que considera as determinantes pessoais do juiz que podem influenciar na tomada a decisão. Embora tais elementos não se mostrem legítimos e suficientes para embasar o fundamento da prova, eles são circunstâncias que precisam ser sopesadas para permitir a devida compreensão das relações inerentes ao campo jurídico-penal. Por isso, também deve haver uma ligação cognitiva com os fatos, que aportará critérios e limitará o processo de convencimento do julgador.

2. Sustenta-se que a liberdade na "valoração racional motivada" representa somente a ausência de critérios previa e abstratamente definidos que vinculem o julgador e excluam a valoração específica no caso concreto, mas de nenhum modo permite uma completa discricionariedade na tomada da decisão. Ou seja, por outro lado, o juízo fático não é livre, pois deve ser orientado por critérios objetivos e racionais, constitucional e convencionalmente dirigidos, de modo a possibilitar um efetivo controle sobre a decisão judicial.

3. O juízo fático é elemento fundamental e central da decisão penal, que, com a condenação, libera o exercício do poder punitivo estatal. Primeiramente, é basilar reforçar o dever de motivação, que necessariamente deve abarcar de modo exaustivo o juízo fático tomado como base na decisão. Somente o dever de motivação e de publicidade, entretanto, não são suficientes para um controle efetivo da sentença. É indispensável que exista mecanismo jurídico que permita a correção do erro com possibilidade de consequências concretas ao caso específico em análise. Partindo-se da premissa assentada anteriormente no sentido da necessidade de um sistema racional de valoração da prova, pautado por critérios objetivos e controláveis intersubjetivamente, a impugnação sobre o juízo fático determinado na sentença condenatória é um elemento potencializador da racionalidade do processo e de sua consolidação como instrumento de limitação do poder punitivo.

\section{REFERÊNCIAS}

ALCÁCER GUIRAO, Rafael. El Derecho a una Segunda Instancia con Todas las Garantías. Valencia: Tirant lo Blanch, 2013..

ALMEIDA JÚNIOR, João Mendes de. 0 processo criminal brazileiro. Vol. 1. 4. ed. Rio de Janeiro: Batista de Souza, 1920. 
ALMEIDA, Vitor L. A apreciação judicial da prova nos sistemas de valoração. Jurisprudência Mineira, Belo Horizonte, v. 65, n. 208, p. 27-33, jan./mar. 2014.

AMARAL, Augusto J. Política da prova e cultura punitiva: a governabilidade inquisitiva do processo penal brasileiro contemporâneo. São Paulo: Almedina, 2014.

AMORIM, Guilherme Freitas. Os controles de racionalidade na valoração da prova no processo penal. Revista de Estudos Criminais, Porto Alegre, v. 10, n. 36, p. 159-182, jan./mar. 2010.

ANDRADE, Flávio da Silva. A construção participada da decisão penal no Estado Democrático de Direito: a garantia de participação das partes, pelo contraditório, na composição da decisão justa e legítima. Revista Brasileira de Direito Processual Penal, Porto Alegre, vol. 3, n. 3, p. 1007-1041, set./dez. 2017. Disponível em: <https://doi.org/10.22197/rbdpp.v3i3.83>. Acesso em: 19 ago. 2018.

ANDRÉS IBÁÑEZ, Perfecto. Acerca de la motivación de los hechos en la sentencia penal. Doxa: Cuadernos de Filosofia del Derecho, n. 12, p. 257-299, 1992. Disponível em: <https://doi.org/10.14198/doxa1992.12.08>. Acesso em: 19 ago. 2018.

ANDRÉS IBÁÑEZ, Perfecto. Prueba y convicción judicial en el proceso penal. Buenos Aires: Hammurabi, 2009. (tradução livre)

ANDRÉS IBÁÑEZ, Perfecto. Sobre el valor de la inmediación (una aproximación crítica). Jueces para la democracia, n. 46, p. 57-66, mar. 2000.

ARAGONESES ALONSO, Pedro. Instituciones de Derecho Procesal Penal. 3. ed. Madrid: Rubi, 1981.

BADARÓ, Gustavo H. A busca da verdade no processo penal e os seus limites: ainda e sempre o problema do prazo de duração da interceptação telefônica. In: SANTORO, Antonio E.; MADURO, Flávio M. (orgs.). Interceptação telefônica. Belo Horizonte: D’Plácido, 2016.

BADARÓ, Gustavo H. Editorial dossiê “Prova penal: fundamentos epistemológicos e jurídicos”. Revista Brasileira de Direito Processual Penal, Porto Alegre, vol. 4, n. 1, p. 43-80, jan./abr. 2018. Disponível em: <http://dx.doi.org/10.22197/rbdpp.v4i1.138>. Acesso em: 19 ago. 2018.

BADARÓ, Gustavo Henrique. Manual dos Recursos Penais. São Paulo: RT, 2016.

BADARÓ, Gustavo Henrique. Ônus da prova no processo penal. São Paulo: RT, 2003.

BADARÓ, Gustavo Henrique. Processo Penal. 2. ed. Rio de Janeiro: Elsevier, 2014.

BARROS, Marco Antonio de. A busca da verdade no processo penal. 4. ed. São Paulo: RT, 2013.

BETTIOL, Giuseppe. Instituciones de Derecho Penal y Procesal. Barcelona: Bosch, 1973. p. 250; CRUZ, Rogerio Schietti M. Garantias Processuais nos Recursos Criminais. 2. ed. São Paulo:

Atlas, 2013. p. 1, nota 1. 
CAPRIOLI, Francesco. Verità e giustificazione nel processo penale. Revista Brasileira de Direito Processual Penal, Porto Alegre, vol. 3, n. 1, p. 317-342, jan./abr. 2017. Disponível em: <https://doi.org/10.22197/rbdpp.v3i1.30>. Acesso em: 19 ago. 2018.

CASARA, Rubens R. R. Mitologia Processual Penal. São Paulo: Saraiva, 2015.

CATALANO, Elena M. Ragionevole dubbio e logica della decisione. Milano: Giuffrè. 2016.

CORDERO, Franco. Procedimiento Penal. Vol. II. Santa Fe de Bogotá: Temis, 2000.

CRUZ, Rogerio Schietti M. Garantias Processuais nos Recursos Criminais. 2a ed. São Paulo: Atlas, 2013.

DIAS, Jorge de Figueiredo. Direito Processual Penal. Coimbra: Coimbra Editora, 2004.

DUCLERC, Elmir. Prova Penal e Garantismo: uma investigação crítica sobre a verdade fática construída através do processo. Rio de Janeiro: Lumen Juris, 2004.

FERNÁNDEZ LÓPEZ, Mercedes. Prueba y presunción de inocencia. Madrid: lustel, 2005.

FERRAJOLI, Luigi. Direito e Razão. Teoria do Garantismo Penal. 4. ed. São Paulo: RT, 2014.

FERRAJOLI, Luigi. Los valores de la doble instancia y de la nomofilaquia. Crimen y Castigo: Cuaderno del Departamento de Derecho Penal y Criminología de la Facultad de Derecho, Buenos Aires, v. 1, n. 1, p. 33-50, ago. 2001. (tradução livre)

FERRER BELTRÁN, Jordi. La valoración racional de la prueba. Madrid: Marcial Pons, 2007.

FERRER BELTRÁN, Jordi. Prueva y verdade en el derecho. 2. ed. Madrid: Marcial Pons, 2005. (tradução livre).

FERRER BELTRÁN, Jordi. Uma concepção minimalista e garantista de presunção de inocência. Revista Brasileira de Direito Processual Penal, Porto Alegre, vol. 4, n. 1, p. 149-182, jan./abr. 2018. Disponível em: <https://doi.org/10.22197/rbdpp.v4i1.131>. Acesso em: 19 ago. 2018.

FERRETI, Carlos del Río. Estudio sobre el derecho al recurso en el proceso penal. Estudios Constitucionales, ano 10, n. 01, p. 245-288, 2012. (tradução livre). Disponível em: <https://doi.org/10.4067/s0718-52002012000100007>. Acesso em: 19 ago. 2018.

FERRUA, Paolo. La prova nel processo penale. Revista Brasileira de Direito Processual Penal, Porto Alegre, vol. 4, n. 1, p. 81-128, jan./mai. 2018. Disponível em:

<https://doi.org/10.22197/rbdpp.v4i1.130>. Acesso em: 19 ago. 2018.

FUENTES MAUREIRA, Claudio. Derecho a recurso y el estándar fijado en el fallo Herrera Ulloa: una lectura hacia su compatibilidad con los sistemas procesales penales acusatorios. Revista CEJIL, ano IV, n. 05, p. 74-82, dez. 2009. (tradução livre).

GASCÓN ABELLÁN, Maria. Los hechos en el derecho. Bases argumentales de la prueba. 3. ed. Madrid: Marcial Pons, 2010. 
GAUER, Ruth C. Conhecimento e aceleração (mito, verdade e tempo). In: GAUER, Ruth C. (org.). A qualidade do tempo: para além das experiências históricas. Rio de Janeiro: Lumen Juris, 2004.

GOMES FILHO, Antonio Magalhães. A motivação das decisões penais. 2a ed. São Paulo: RT, 2013.

GOMES FILHO, Antonio Magalhães. Direito à prova no processo penal. São Paulo: RT, 1997.

GRINOVER, Ada Pellegrini. Provas ilícitas, interceptações e escutas. Brasília: Gazeta Jurídica, 2013.

GRINOVER, Ada Pellegrini. Verdade real e verdade formal? Um falso problema. In: PEREIRA, Flávio Cardoso. Verdade e prova no processo penal. Brasília: Gazeta Jurídica, 2016.

HARTMANN, Érica O. Os sistemas de avaliação da prova e o processo penal brasileiro. Revista da Faculdade de Direito UFPR, Curitiba, v. 39, p. 109-123, 2003. Disponível em:

<https://doi.org/10.5380/rfdufpr.v39i0.1749>. Acesso em: 19 ago. 2018.

HERBEL, Gustavo A. La motivación de la condena y su revisión amplia como garantías del imputado (¿puede el juicio por jurados restringirlas?). Revista de Derecho Penal y Procesal Penal, Buenos Aires, n. 4, p. 679-687, 2013. (tradução livre)

IACOVIELLO, Francesco M. La motivazione della sentenza penale e il suo controllo in cassazione. Milano: Giuffrè, 1997.

KHALED JR., Salah H. A busca da verdade no processo penal. Para além da ambição inquisitorial. São Paulo: Atlas, 2013.

KNIJNIK, Danilo. A prova nos juízos cível, penal e tributário. Rio de Janeiro: Forense, 2007.

LLORENTE SÁNCHEZ-ARJONA, Mercedes. La segunda instancia en el proceso penal. Doctrina y jurisprudencia. Granada: Comares, 2000.

LOPES JR., Aury. Direito Processual Penal. 9. ed. São Paulo: Saraiva, 2012.

LÓPEZ ORTEGA, Juan J. El control de los hechos en el juicio de apelación. Jueces para la democracia, Madri, v. 66, p. 101-117, nov. 2009. (tradução livre).

MALAN, Diogo. Notas sobre a investigação e prova da criminalidade econômico-financeira organizada. Revista Brasileira de Direito Processual Penal, Porto Alegre, vol. 2, p. 213-238, 2016. Disponível em: <https://doi.org/10.22197/rbdpp.v2i1.22>. Acesso em: 19 ago. 2018.

MARTINS, Rui Cunha. O Ponto Cego do Direito. The brazilian lessons. 2a ed. Rio de Janeiro: Lumen Juris, 2011.

MAYA, André M.; URANI, Marcelo F. O princípio da identidade física do juiz e a função persuasiva da prova no processo penal. In: FAYET JR., Ney; MAYA, André M. (orgs.). Ciências penais e sociedade complexa II. Porto Alegre: Nuria Fabris, 2009. 
MENDES, Regina Lúcia Teixeira. Do Princípio do Livre Convencimento Motivado. Legislação, doutrina e interpretação de juízes brasileiros. Rio de Janeiro: Lumen Juris, 2011.

NIEVA FENOLL, Jordi. La duda en el proceso penal. Madrid: Marcial Pons, 2013.

NIEVA FENOLL, Jordi. La valoración de la prueba. Madrid: Marcial Pons, 2012.

PACELLI, Eugênio. Verdade judicial e sistema de prova no processo penal brasileiro. In: PEREIRA, Flávio Cardoso. Verdade e prova no processo penal. Brasília: Gazeta Jurídica, 2016.

PASTOR, Daniel R. La nueva imagen de la casación penal. Evolución histórica y futuro de la dogmática de la impugnación en el derecho procesal penal. Buenos Aires: Ad-Hoc, 2001. (tradução livre).

PINTO, Felipe Martins. Introdução crítica ao processo penal. Belo Horizonte: Del Rey, 2012.

PRADO, Geraldo. Prova penal e sistema de controle epistêmicos. São Paulo: Marcial Pons, 2014.

RICHARD GONZÁLEZ, Manuel. La impugnación y revisión de la prueba mediante los recursos ordinarios y extraordinarios en el proceso penal. In: LLUCH, Xavier Abel; GONZÁLEZ, Manuel Richard (Dir.). Estudios sobre prueba penal: actos de investigación y medios de prueba en el proceso penal: diligencias de instrucción, entrada y registro, intervención de comunicaciones, valoración y revisión de la prueba en vía de recurso. Madrid: La Ley, 2013.

ROSA, Alexandre Morais da. Guia Compacto do Processo Penal conforme a Teoria dos Jogos. 3. ed. Florianópolis: Empório do Direito, 2016.

SALAVERRIA, Juan. Valoración de la prueba, motivación y control en el proceso penal. Valencia: Tirant lo Blanch, 1995.

SÁNCHEZ-RUBIO, Ana. Los peligros de la probabilidad y la estadística como herramientas para la valoración jurídico-probatoria. Revista Brasileira de Direito Processual Penal, Porto Alegre, vol. 4, n. 1, p. 183-214, jan./abr. 2018. Disponível em:

<https://doi.org/10.22197/rbdpp.v4i1.118>. Acesso em: 19 ago. 2018.

SANTOS, André Leonardo Copetti. A Incompatibilidade das Decisões do Conselho de Sentença do Tribunal do Júri com o Estado Democrático de Direito: uma interpretação da legitimidade das decisões judiciais a partir de uma interseção entre filosofia e direito. Sistema Penal \& Violência, Porto Alegre, vol. 3, n. 1, p. 30-46, jan./jun. 2011.

STRECK, Lenio L. 0 que é isto - decido conforme a minha consciência? 4a ed. Porto Alegre: Livraria do Advogado, 2013.

STRECK, Lenio Luiz. A filosofia traída pela dogmática jurídica: uma crítica à noção de verdade e ao livre convencimento no processo penal. In: MALAN, Diogo; MIRZA, Flávio (coord.). 70 anos do Código de Processo Penal brasileiro. Balanço e perspectivas de reforma. Rio de Janeiro: Lumen Juris, 2011. 
SUAU MOREY, Jaime. Inmediación y Apelación en el Proceso Penal. Jurisprudencia TC y reformas procesales. Barcelona: JM Bosch, 2010.

TARUFFO, Michele. Consideraciones sobre prueba y motivación. Jueces para la democracia. Madri, v. 59, p. 71-79, jul. 2007.

TARUFFO, Michele. Ermeneutica, prova e decisione. Revista Brasileira de Direito Processual Penal, Porto Alegre, vol. 4, n. 1, p. 129-148, jan./abr. 2018. Disponível em: <https://doi.org/10.22197/rbdpp.v4i1.136>. Acesso em: 19 ago. 2018.

TARUFFO, Michele. La prueba de los hechos. 4. ed. Madrid: Trotta, 2011.

TARUFFO, Michele. La verità nel processo. In: PEREIRA, Flávio Cardoso. Verdade e prova no processo penal. Brasília: Gazeta Jurídica, 2016.

TUCCI, Rogério Lauria. Direitos e garantias individuais no processo penal brasileiro. 4. ed. São Paulo: RT, 2011.

VASCONCELLOS, Vinicius G. Direito ao Recurso no Processo Penal: conteúdo e dinâmica procedimental de um modelo de limitação do poder punitivo estatal pelo controle efetivo da sentença condenatória. 2017. Tese (Doutorado em Direito) - Faculdade de Direito, Universidade de São Paulo, São Paulo.

VASCONCELLOS, Vinicius G. 0 'Sistema Acusatório' do Processo Penal Brasileiro: Apontamentos Acerca do Conteúdo da Acusatoriedade a partir de Decisões do Supremo Tribunal Federal.

Direito, Estado e Sociedade, n. 47, p. 181-204, jul./dez. 2015. Disponível em: <https://doi.org/10.17808/des.47.604>. Acesso em: 19 ago. 2018.

VASCONCELLOS, Vinicius G.; GALÍCIA, Caíque R. Tribunal do Júri na Justiça Criminal Brasileira: críticas e propostas de reforma para a restituição de sua função de garantia no processo penal democrático. Revista Eletrônica de Direito Processual, Rio de Janeiro, vol. XIII, p. 903-929, jan./jun. 2014.

ZILLI, Marcos Alexandre Coelho. A Iniciativa Instrutória do Juiz no Processo Penal. São Paulo: RT, 2003.

\section{COMO FAZER A REFERÊNCIA DO ARTIGO (ABNT):}

VASCONCELLOS, Vinicius Gomes de. A prova no processo penal: a importância da valoração do lastro probatório e de seu controle por meio recursal. Revista Eletrônica do Curso de Direito da UFSM, Santa Maria, RS, v. 13, n. 2, p. 695721, ago. 2018. ISSN 1981-3694. Disponível em: < https://periodicos.ufsm.br/revistadireito/article/view/30012 >. Acesso em: dia mês. ano. doi: http://dx.doi.org/10.5902/1981369430012 . 